\title{
Double staining in situ study of mRNAs encoding milk proteins in the mammary gland of the tammar wallaby (Macropus eugenii)
}

\author{
R. Joseph and C. Collet \\ CSIRO Division of Wildlife and Ecology, PO Box 84, Lyneham, ACT, Australia, 2602
}

\begin{abstract}
Oligonucleotides, differentially tagged with fluorochromes, were used to determine whether the distribution of mRNAs encoding the major milk proteins is heterogeneous within the mammary gland of the tammar wallaby (Macropus eugenii). This method also allowed direct visualization of two species of mRNA within the same cell. Sections of early and late lactating glands of tammar wallabies were hybridized with oligonucleotides labelled with fluorescein isothiocyanate or rhodamine isothiocyanate either alone or in combination. The results support the hypothesis that milk secretion is an all-or-none process with all epithelial cells in a given alveolus producing the same suite of milk proteins. In tammar wallabies, a gene encoding a protein specific to the latter phase of lactation appears to be expressed in those cells already secreting the other major milk proteins.
\end{abstract}

\section{Introduction}

The reproductive strategies of eutherians and marsupials differ in their relative emphases on gestation and lactation, the marsupial neonate is immature and development continues within the pouch (Tyndale-Biscoe and Renfree, 1987; TyndaleBiscoe and Janssens, 1988). Eutherian milks vary greatly in composition among species but differ only slightly with respect to the concentration of the various constituents during lactation (Jenness, 1974; Cowie, 1984). By contrast, marsupial milk changes in composition to reflect the developmental stage and changing nutritional requirements of the pouch young. The tammar wallaby (Macropus engenii) produces two types of milk, early and late phase, which vary significantly in composition, both qualitatively and quantitatively (Green et al., 1980; Green, 1984; Green and Merchant, 1988). Minor protein species are specific to the early phase of lactation, whereas the latter phase is marked by the appearance of an abundant whey protein termed LLP (or late-lactation protein; Nicholas et al., 1987). The redirection of the metabolic processes of the epithelial cells during the transitional period between early and late lactation is also accompanied by dramatic changes in cellular and glandular morphology (Findlay, 1982; Stewart, 1984). This, in turn, is reflected in a rapid increase in the size of the gland (Stewart, 1984).

This paper presents an in situ hybridization study of tammar mammary gland sections using oligonucleotide probes labelled with different fluorescent tags. Application of different wavelengths of UV allowed the direct visualization of different mRNA species within the same cell. This technique was used to study the glandular and cellular distribution of the mRNAs encoding the major milk proteins in the early and late phases of lactation in tammar wallabies. Glandular or lobular specialization is a possibility given that induction of gene expression of

*Correspondence.

Revised manuscript received 4 January 1994. the four major milk proteins, $\alpha$-lactalbumin, $\beta$-lactoglobulin and $\alpha$ - and $\beta$-casein, is under different regimens of hormonal control (Collet et al., 1990, 1991, 1992). Of particular interest is the distribution of cells synthesizing LLP.

In situ hybridization has been used extensively to localize mRNA species in tissue sections and DNA fragment position on chromosomes. Co-localization by double staining of a single section has been achieved by combining immunocytochemistry and in situ hybridization to co-localize mRNA and peptides in a single section (Shivers et al., 1986; Couwenhoven et al., 1990). Dirks et al. (1990) further refined the technique of simultaneously detecting different substances in the one section by using oligonucleotide probes labelled with fluorescein isothiocynate (FITC) and biotin to double stain ganglia for neural hormone mRNA. Although three colour fluorescence has been used to detect different DNA fragments on chromosomes simultaneously, using an antibody to each fluorochrome to amplify the signal (Nederlof et al., 1989; Reid et al., 1992), the use of two or more fluorescently tagged DNA fragments in the direct localization of mRNA in tissue sections has not yet been reported.

\section{Materials and Methods}

\section{Collection of mammary glands}

The lactation period of tammar wallabies is approximately 300 days. Early phase lactation covers the period from day 4 to day 140 after parturition, the transitional period covers days 140-190 and the late phase accounts for the remaining period. Mammary gland biopsies were taken from tammar wallabies, following the guidelines of the CSIRO Institutional Animal Care and Experimentation Ethics Committee, during the early (on days 20, 65, and 120; number of animals $=$ number of glands $=8$ ) and the late (on 200, 210 and 290 days; number of animals $=$ number of glands $=8$ ) phases of lactation, fixed in 
Serra's fixative and embedded in paraffin wax following standard procedures. Serial sections were cut at $7 \mu \mathrm{m}$ onto washed, siliconized slides. Serial sections were divided into groups of 10; one section from each group was treated as a control (either sense oligonucleotide or no probe), one section was stained with haematoxylin and eosin and the other sections were challenged with different oligonucleotide probe combinations.

\section{Probe construction}

Anti-sense and sense (control) oligonucleotides were constructed using a Pharmacia Gene Assembler Plus oligonucleotide synthesizer. The sequences of the oligonucleotides correspond to the region 64-ATGAGGGTCCTGTTCCT-80 of LLP, 46-ATGATGTCTCTGCTCTC-62 of $\alpha$-lactalbumin, 10-GTTGGATTGGCCCTCAT-26 of $\beta$-lactoglobulin, and 1-AACCTCCCTTTGGCTCA-17 of $\alpha$-casein and 19CTCCTCTTGAGGAAAGA-35 of $\beta$-casein (Collet et al, 1989, $1990,1991,1992$, respectively). The oligonucleotides were 5 '-labelled with either fluorescein isothiocyanate (FITC) or rhodamine isothiocyanate (RITC) following the protocol provided by Pharmacia (Uppsala) for Auto-primer synthesis. All reagents were supplied by Pharmacia except for the RITC, which was purchased from Sigma (Madison, WI).

In situ hybridization

Mammary gland sections were deparaffinized and rehydrated following standard procedures. Sections were refixed for $5 \mathrm{~min}$, at $4^{\circ} \mathrm{C}$ in $0.4 \%$ paraformaldehyde, washed in water and then treated with proteinase $\mathrm{K}$ ( $100 \mathrm{ng} \mathrm{ml}^{-1}$ ) (Promega) for $7.5 \mathrm{~min}$ at room temperature and refixed for $5 \mathrm{~min}$ at $4^{\circ} \mathrm{C}$ in $0.4 \%$ paraformaldehyde. Hybridization buffer $(0.8 \times$ Denhardts solution, $0.1 \mathrm{mg}$ salmon sperm DNA, $3 \times \mathrm{SSC}$ $\left(\mathrm{SSC}=0.15 \mathrm{~mol} \mathrm{NaCl} \mathrm{l}^{-1}, 0.015 \mathrm{~mol} \mathrm{NaCl} l^{-1}, \mathrm{pH} 7.0\right), 40 \%$ formamide [Analar], in $7.0 \mathrm{ml}$ ) was applied to the sections and the slides were incubated for $2 \mathrm{~h}$ at $40^{\circ} \mathrm{C}$. Approximately 120 sections were examined for each treatment per experiment. The oligonucleotide probe was applied at a concentration of $20 \mathrm{ng}$ $\mathrm{ml}^{-1}$ in hybridization buffer and the slides were placed on a heating block at $90^{\circ} \mathrm{C}$ for $6 \mathrm{~min}$, and then on ice for $1 \mathrm{~min}$. Hybridizations were carried out overnight at $40^{\circ} \mathrm{C}$. The sections were washed in $2 \times$ SSC for $10 \mathrm{~min}$ at $40^{\circ} \mathrm{C} ; 2 \times \mathrm{SSC}$ for $60 \mathrm{~min}$ at $40^{\circ} \mathrm{C} ; 0.1 \times \mathrm{SSC}$ for $10 \mathrm{~min}$ at room temperature; $0.1 \times$ SSC for $60 \mathrm{~min}$ at room temperature. The sections were then mounted in Kaiser's buffered glycerol (Merck, Darmstadt), and analysed using a Leitz Diaplan fluorescent microscope with blue $(49 \mathrm{~nm})$ and green $(56 \mathrm{~nm})$ filters as provided by Leitz. Incubations of more than $60 \mathrm{~min}$ were carried out in a humid chamber. Double staining was achieved by applying two probes (each at $20 \mathrm{ng} \mathrm{ml}^{-1}$ ) to the same section. Sections were also challenged with hybridization buffer alone as an additional control. All reagents were made up in diethylpyrocarbonate (DEPC)-treated, autoclaved doubledistilled water and contained RNase inhibitor (RNAsin, Promega) at $180 \mathrm{U} \mathrm{ml}^{-1}$.
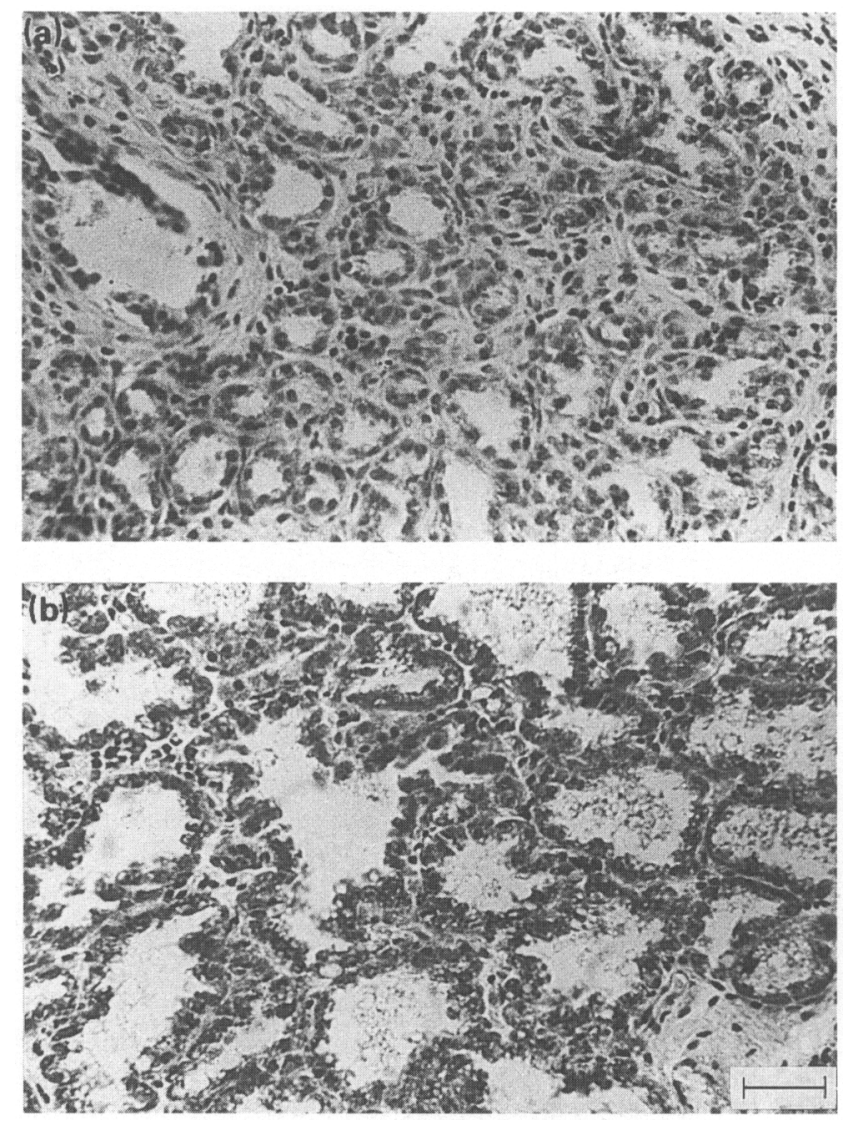

Fig. 1. Haematoxylin and eosin stained mammary gland section from tammar wallaby. (a) Early lactation; (b) late lactation. Scale bar represents $100 \mu \mathrm{m}$.

\section{Results}

\section{Cytology}

Sections of mammary gland taken during early lactation (days 20,65 and 120) show numerous small alveoli with connective tissue visible between them (Fig. 1a). The secretory cell nucleus occupied a large proportion of the cellular area, and appeared to be similar to Hollmann's (1974) description of mammary cells of mid-pregnant mice. The cells of mammary glands taken at 200,210 and 290 days (late lactation) were more typical of fully lactating cells: the alveoli were large and little connective tissue was visible (Fig. Ib). The cells around the alveoli were flattened in appearance and the secretory cells occupied a greater total area in late phase glands than in early phase lactation. This increase was partly attributable to a doubling of the cytoplasmic area; the area occupied by the nucleus appeared constant. Few mitotic figures $(<1 \%)$ were seen in all sections, from both phases of lactation, although an increase in binucleated cells was obvious in cells at 200 days of lactation.

\section{Single staining}

After hybridization to sections of early and late phase mammary glands from tammar wallabies, all the control 

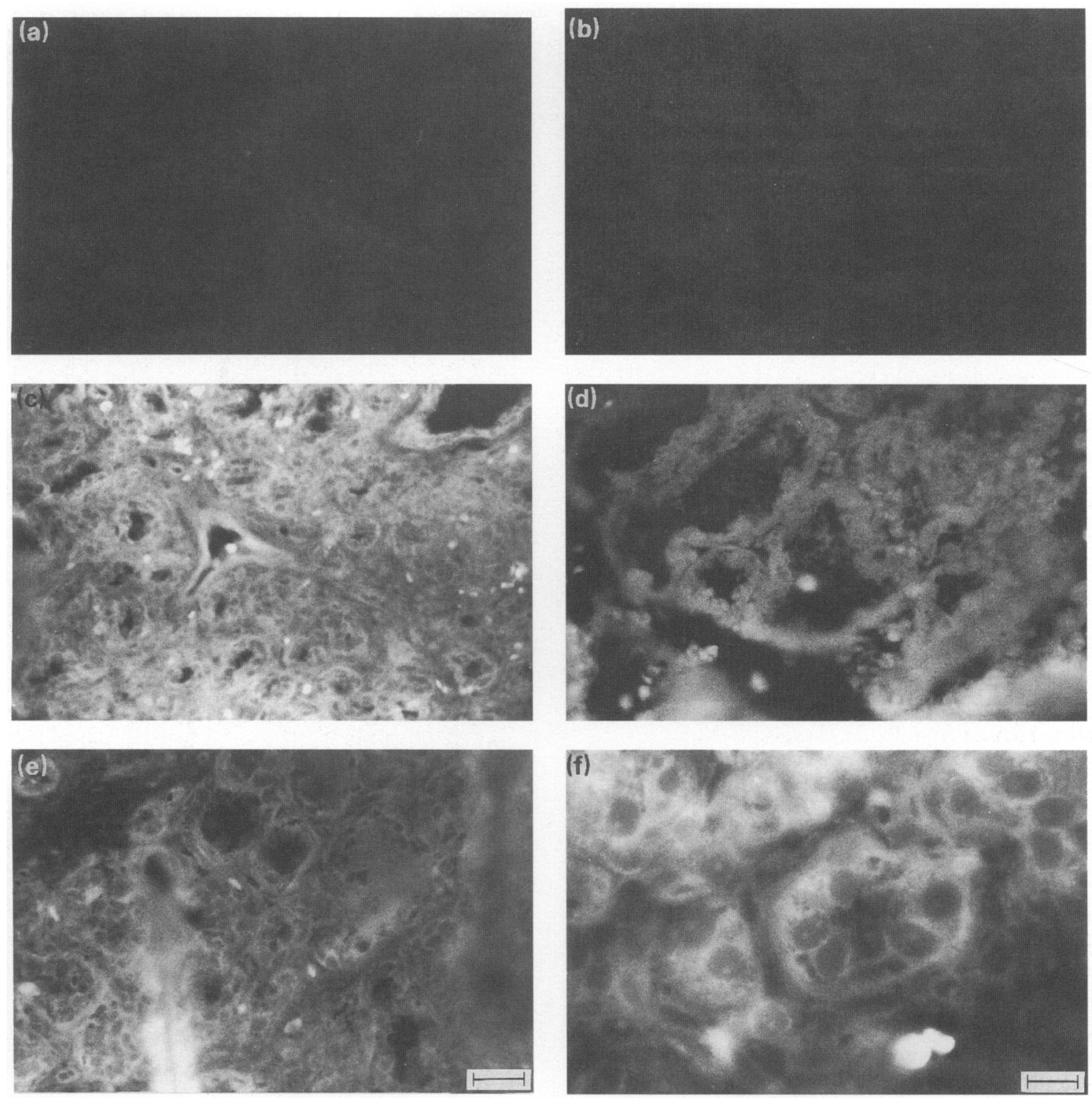

Fig. 2. Sections of early and late mammary gland from tammar wallabies hybridized with the whey and casein oligonucleotides applied singly. In early or late stages, the pattern of hybridization signal produced by each oligonucleotide, whether whey or casein, was similar. (a) Control section: early gland section hybridized without oligonucleotide; (b) contro] section: late gland hybridized with sense late-lactation protein (LLP) olignucleotide; (c) early gland section hybridized with $\alpha$-lactalbumin oligonucleotide; (d) late gland hybridized with $\beta$-lactoglobulin oligonucleotide; (e) early gland hybridized with $\alpha$-casein oligonucleotide; $(f)$ early gland hybridized with $\beta$-casein oligonucleotide. Scale bar represents $(a-e): 100 \mu m$; f: $40 \mu \mathrm{m}$.

treatments (sense oligonucleotides and hybridization buffer alone) showed minimal staining (Fig. 2a, b). Sections of both early and late phase glands demonstrated a similar pattern of staining. Positive hybridization signals were present in the cytoplasm of all alveolar cells for the two caseins, $\alpha$-lactalbumin and $\beta$-lactoglobulin antisense oligonucleotides (Fig. 2c-f). The pattern of staining was easier to discern, owing to the more compact structure of the gland, in sections of early phase gland as rings around the large nucleus of the epithelial cells (Fig. 2c, e; Findlay and Renfree, 1984). Staining of the sections of late phase gland was more concentrated and correlated with both the increased cytoplasmic volume (Fig. $2 \mathrm{~d}, \mathrm{f}$ ) and increased synthesis of milk protein mRNAs (Collet et al, 1990,
1991, 1992). LLP staining was observed only in the sections of late phase gland in a pattern similar to that seen for whey and caseins. Sections of early phase gland incubated with LLP were not different from the control sections. This finding is consistent with the northern analyses, which show that LLP mRNA is present only in late-phase gland (Collet et al., 1989).

\section{Double staining}

Double-probe mixes were used to assess whether the same population of cells was producing more than one species of milk protein mRNA. The double-probe mixtures were: $\alpha$-casein 

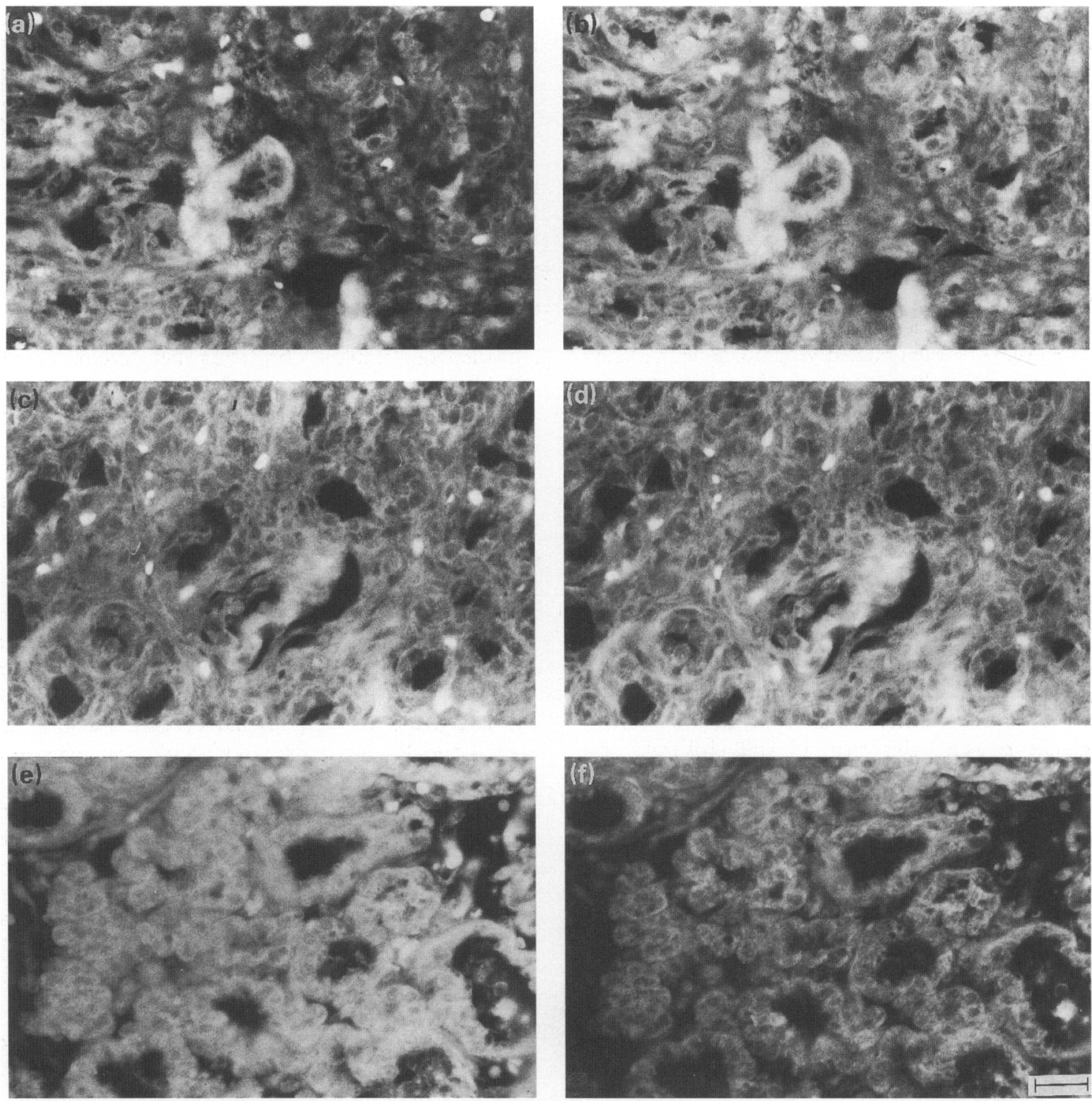

Fig. 3. Sections of early and late phase tammar mammary gland double-stained with oligonucleotides and visualized under different wavelengths of UV. A section of early gland stained with (a) $\alpha$-casein oligonucleotide end-labelled with rhodamine isothiocyanate (RITC) and visualized under UV at $56 \mathrm{~nm}$, and (b) $\beta$-casein oligonucleotide end-labelled with fluorescein isothiocyanate (FITC) and visualized under UV at $49 \mathrm{~nm}$. A section of early gland stained with (c) $\beta$-lactoglobulin (RITC) and (d) $\beta$-casein (FITC) oligonucleotides. A section of late gland stained with (e) late-lactation protein (LLP) (FITC) and (f) $\alpha$-lactalbumin (RITC) oligonucleotides. Scale bar represents $100 \mu \mathrm{m}$.

(RITC)- $\beta$-casein (FITC), $\beta$-lactoglobulin (RITC)- $\beta$-casein, $\alpha$-lactalbumin (RITC)- $\beta$-casein, LLP (FITC)- $\beta$-lactoglobulin, LLP- $a$-lactalbumin and LLP- $a$-casein. Staining of sections of early phase gland showed that the cells that produced $\alpha$-casein also produced $\beta$-casein (Fig. 3a, b). Sections co-stained with $\beta$-lactoglobulin or $\alpha$-lactalbumin and $\beta$-casein demonstrated an identical staining pattern (Fig. 3c,d), indicating that the secretory cells that produce the caseins also produce the major whey proteins. In the sections of late phase gland that were double-labelled for LLP and $\beta$-lactoglobulin or $\alpha$-lactalbumin, the same cells stained for both oligonucleotide probes (Fig. $3 \mathrm{e}, \mathrm{f}$. A similar pattern of hybridization was noted for sections stained for both LLP and $\alpha$-casein. Early gland sections incubated with LLP and either $\alpha$-lactalbumin, $\beta$-lactoglobulin or $\alpha$-casein showed positive staining only for the $\alpha$-lactalbumin, $\beta$-lactoglobulin and $\alpha$-casein mRNAs.

\section{Discussion}

The histological examination undertaken in this study confirms the observations of Findlay (1982) that, although the cytology of the mammary gland of the tammar wallaby is similar to that of eutherian mammary glands (Hollmann, 1974; Cowie, 1984), the time course of the developmental changes throughout lactation appears to differ. At parturition in tammar wallabies, the cytological appearance of the lactating gland is similar to that of mice at mid-pregnancy. A fully lactating appearance, as 
defined cytologically for eutherian mammals, is not reached until the transition between early and late phases of lactation. The mammary gland of the tammar wallaby grows throughout lactation; there is a rapid increase in volume during the transitional period between early and late phase (Stewart, 1984). This increase in size is due, in part, to an increase in the cytoplasm : nucleus ratio and the volume of the lumina associated with the alveoli (Findlay, 1982; this study). A constant DNA content per gram of tissue led Stewart (1984) to suggest that the increase in gland size may be due to an increase in the number of cells. Although few mitotic divisions were apparent in the mammary gland during lactation (Findlay, 1982; this study), DNA replication is undoubtedly occurring as the level of binucleated epithelial cells increases in the latter phase of lactation (data not shown).

This study presents a technique that allows the direct visualization, using different wavelengths of UV, of different mRNA species within the same region of an organ, in fact within the same cell. This level of resolution was essential to resolve questions concerning the distribution of cells synthesizing the highly abundant milk proteins within the mammary gland of the tammar wallaby. The absence of staining on sections hybridized with the sense oligonucleotides indicates high specificity of the probes.

Use of the differentially tagged oligonucleotides, either applied singly or in combination, to thin sections of tammar mammary glands demonstrates that all epithelial cells are producing the same suite of four milk proteins, $\alpha$-lactalbumin, $\beta$-lactoglobulin, $\alpha$-casein and $\beta$-casein, during the early phase of lactation. In late lactation, the cells producing these four milk proteins are also synthesizing another major whey protein, LLP. Thus there does not appear to be any regionalization within the gland with regard to localization of milk protein synthesis. This result does not support the suggestion of Tyndale-Biscoe and Renfree (1987), based on the observations and conclusions of Stewart (1984), that a new population of secretory cells that specifically synthesize LLP may arise during the transitional period. The results presented here also support the hypothesis that milk secretion is an all-or-none process, and that the secretory cells in a given alveolus produce the same suite of proteins (Molenaar et al., 1992).

Rudland and Hughes (1989) reported a differential distribution of antibody staining for $k$-casein and $\beta$-casein proteins in lactating mammary gland of humans in that $\beta$-casein was found in the secretory epithelial cells, while $k$-casein was found in this cell type and also in cells lining the interlobular ducts. Our study demonstrates that both $\alpha$-casein and $\beta$-casein mRNAs are synthesized by the same epithelial cells. Staining of the interlobular ducts was not evident in hybridizations with the tagged oligonucleotides used in this study, which is consistent with the findings of Rudland and Hughes (1989). Since the casein micelle is secreted as an intact membranebound structure (Pearse et al., 1986), it is not clear why there may be differential staining for the two casein peptides in the study by Rudland and Hughes (1989).

The results reported here contrast with those of an in situ hybridization study that examined the distribution of $\alpha$-lactalbumin, $\alpha_{\mathrm{Sl}^{-}}$-casein and lactoferrin mRNA in the mammary glands of sheep (Molenaar et al., 1992). Although serial sections were not used, these authors concluded, on the basis of alveoli morphology, that $\alpha$-lactalbumin and $\alpha_{\mathrm{SI}}$-casein were expressed in the same cells, while lactoferrin was expressed in 'fatty alveoli'. The two classes of alveoli (fatty and non-fatty) described by Molenaar et al. (1992) (presumably the filling and resting alveoli of Hollmann (1974)) were not observed in the mammary gland of tammar wallabies. In sheep, the regionalization of $\alpha$-lactalbumin- $\alpha_{\mathrm{Sl}}$-casein and lactoferrin appeared to be sharply defined, with some alveoli, by inference, producing both $\alpha$-lactalbumin and $\alpha_{\mathrm{SI}^{-}}$-casein and other alveoli producing lactoferrin (Molenaar et al., 1992). Regions of differential staining intensity were evident in the mammary glands of tammar wallabies (data not shown). There appeared to be no structural or technical reason for the patterns of differential hybridization. However, the regions of dissimilar staining intensity were not as defined as that described for sheep. This may reflect the sensitivity of oligonucleotides as probes compared with the use of longer cRNA probes.

This report shows that, in early lactation, each alveolar cell synthesizes all of the major milk proteins. In late lactation, the alveolar cells also synthesize a stage-specific protein, LLP. The mechanisms controlling the onset of late phase lactation, and thereby the induction of LLP, in tammar wallabies are unknown. Some evidence suggests that prolactin may be involved as concentrations of prolactin increase in plasma by ten times at the beginning of the transition (Hinds and Tyndale-Biscoe, 1982; Hinds and Tyndale-Biscoe, 1985). However, the application in vitro of physiological concentrations of prolactin to mammary gland explants from glands taken from tammar wallabies early in lactation failed to elicit the induction of LLP (Nicholas, 1988). The involvement of factors, endocrine or autocrine, in the significant redirection of the metabolic processes of the mammary glands of tammar wallabies during the transition from early to late phase lactation remains to be elucidated.

C. Collet was the recipient of an Australian Research Council Fellowship. The authors wish to thank L. Hinds for animal husbandry.

\section{References}

Collet C, Joseph R and Nicholas KR (1989) Molecular cloning and characterisation of a novel marsupial milk protein gene Biochemical and Biophysical Research Communications 164 1380-1383

Collet C, Joseph R and Nicholas KR (1990) Cloning, cDNA analysis and prolactin-dependent expression of a marsupial $\alpha$-lactalbumin Reproduction Fertility and Development 2 693-701

Collet C, Joseph R and Nicholas KR (1991) A marsupial $\beta$-lactoglobulin: characterisation and prolactin-dependent expression Journal of Molecular Endocrinology 6 19-26

Collet C, Joseph R and Nicholas KR (1992) Molecular characterisation and in vitro hormonal requirements for gene expression of two casein genes of a marsupial Joumal of Molecular Endocrinology 8 13-20

Couwenhoven RI, Lou W and Snead ML (1990) Co-localisation of EGF transcripts and peptides by combined immunohistochemistry and in situ hybridisation Journal of Histochemistry and Cytochemistry 38 1853-1857

Cowie AT (1984) Lactation. In Reproduction in Mammals Book 3: Hormonal Control of Reproduction pp 195-231 Eds CR Austin and RV Short. Cambridge University Press, Cambridge

Dirks RW, van Gijlwijk RPB, Tullis RH, Smit AB, van Minnen J, van der Ploeg M and Raap AK (1990) Simultaneous detection of different mRNA sequences coding for neuropeptide hormones by double in situ hybridisation using FITC- and biotin-labelled oligonucleotides Journal of Histochemistry and Cytochemistry 38 467-473 
Findlay L (1982) The mammary glands of the tammar wallaby (Macropus eugenii) during pregnancy and lactation Journal of Reproduction and Fertility 65 $59-66$

Findlay L and Renfree M (1984) Growth, development and secretion of the mammary gland of macropodid marsupials Symposia of the Zoological Society of London 51 403-432

Green B (1984) Composition of milk and energetics of growth in marsupials Symposium of the Zoological Society of London 51 369-387

Green B and Merchant JC (1988) The composition of marsupial milk. In The Developing Marsupial: Models for Biomedical Research pp 41-54 Eds $\mathrm{CH}$ Tyndale-Biscoe and PA Janssens. Springer-Verlag, Berlin

Green B, Newgrain K and Merchant J (1980) Changes in milk composition during lactation in the tammar wallaby (Macropus engenii) Australian Joumal of Biological Sciences 33 35-42

Hinds LA and Tyndale-Biscoe CH (1982) Prolactin in the marsupial Macropus eugenii during the estrous cycle, pregnancy and lactation Biology of Reproduction 26 391-398

Hinds LA and Tyndale-Biscoe CH (1985) Seasonal and circadian patterns of circulating prolactin during lactation and seasonal quiescence in the tammar, Macropus eugenii Joumal of Reproduction and Fertility 74 173-183

Hollmann KH (1974) Cytology and fine structure of the mammary gland. In Lactation: A Comprehensive Treatise Vol I pp 3-95 Eds BL Larson and VR Smith. Academic Press, New York

Jenness $\mathbf{R}$ (1974) The composition of milk. In Lactation: A Comprehensive Treatise Vol III pp 3-107 Eds BL Larson and VR Smith. Academic Press, New York

Molenaar AJ, Davis SR and Wilkins RJ (1992) Expression of a-lactalbumin, $\alpha_{\mathrm{SI}}$-casein, and lactoferrin genes is heterogeneous in sheep and cattle mammary tissue Journal of Histochemistry and Cytochemistry 40 611-618

Nederlof PM, Robinson D, Abuknesha R, Wiegant J, Hopman AHN, Tanke HJ and Raap AK (1989) Three-colour fluorescence in situ hybridisation for the simultaneous detection of multiple nucleic acid sequences Cytometry 10 $20-27$
Nicholas KR (1988) Asynchronous dual lactation in a marsupial, the tammar wallaby (Macropus eugenii) Biochemical and Biophysical Research Communications 154 529-536

Nicholas KR, Messer M, Elliott C, Maher F and Shaw D (1987) A novel whey protein synthesised only in late lactation by the mammary gland from the tammar (Macropus eugenii) Biochemical Journal 241 899-904

Pearse MJ, Linklater PM, Hall RJ and Mackinlay AG (1986) Effect of casein micelle composition and casein dephosphorylation on coagulation and syneresis Journal of Dairy Research 53 381-390

Reid T, Baldini A, Rand TC and Ward DC (1992) Simultaneous visualisation of seven different DNA probes by in situ hybridisation using combinatorial fluorescence and digital imaging microscopy Proceedings of the National Academy of Sciences USA 89 1388-1392

Rudland PS and Hughes CM (1989) Immunological identification of cell types in human mammary gland: variations in cellular markers are dependent on glandular topography and differentiation Journal of Histochemistry and Cytochemistry 37 1087-1100

Shivers BD, Harlan RE, Pfaff DW and Schachter BS (1986) Combination of immunocytochemistry and in situ hybridisation in the same tissue section of rat pituitary Journal of Histochemistry and Cytochemistry 34 39-43

Stewart F (1984) Mammogenesis and changing prolactin receptor concentrations in the mammary glands of the tammar wallaby (Macropus eugenii) Journal of Reproduction and Fertility 71 141-148

Tyndale-Biscoe CH and Janssens PA (eds) (1988) The Developing Marsupial: Models for Biomedical Research. Springer-Verlag, Berlin

Tyndale-Biscoe CH and Renfree M (1987) Reproductive Physiology in Marsupials. Cambridge University Press, Cambridge 